\title{
EFFECT OF TEMPERATURE OF HEAT TREATMENT ON ENERGETIC INTENSITY OF FLAT MILLING OF PICEA ABIES
}

\author{
Peter KOLEDA, Michal KORČOK, Štefan BARCÍK, Štefan ILAŠ \\ Technical University in Zvolen
}

\begin{abstract}
:
The paper deals with the research of the influence of thermal modification temperature of spruce wood on the electric energy consumption of its face milling. Samples of spruce wood heat treated at temperatures of $160,180,200$ and $220^{\circ} \mathrm{C}$ were milled at the cutting speed of 20,40 and $60 \mathrm{~m} . \mathrm{s}-1$, the feed rate of 6,10 and 15 $\mathrm{m}$. min- 1 , the rake angle of $15^{\circ}$ with the depth of the cut of $1 \mathrm{~mm}$. The energy consumption was evaluated from the cutting power, which was based on the difference during milling and idle cycle. The analysis of variance showed a decrease in cutting power with an increasing temperature of thermal modification. The average cutting power value is $137.7 \mathrm{~W}$ at the native sample and $80.8 \mathrm{~W}$ at the sample treated at $220^{\circ} \mathrm{C}$. The Duncan's test of statistical significance has shown that the thermal modification has a statistically significant effect on the cutting power values.
\end{abstract}

Key words: ThermoWood, face milling, cutting power, energetic efficiency, picea abies

\section{INTRODUCTION}

Wood has a very wide range of uses, especially in construction, furniture and paper industry, transport, and others. A very important feature of wood is its natural durability in various exterior and more demanding indoor exposures. One possibility of changing and improving the properties of wood materials is thermal modification. It is based on thermal and hydrothermal wood treatment at high temperatures in the range of 150 to $260^{\circ} \mathrm{C}$ [4]. The high temperatures degrade some wood building polymers to form new water-insoluble substances and also substances with a toxic or repellent effect against biological pests of wood. Strength and some mechanical properties decrease in heat treated wood due to the decrease in density $[21,22]$ as well as hemicellulose disruption and increased hydrophobicity of the surface $[1,14]$. The mechanical properties are significantly reduced if the heat treatment of the wood is carried out in an inert environment without access of oxygen - for example in vacuum, nitrogen or oil [19].

At temperatures above $150-170^{\circ} \mathrm{C}$, in addition to plasticizing processes, the chemical structure of the treated wood begins to change significantly. Hydrophilic functional groups start to terminate in structures of polysaccharides, lignin and accompanying materials. Depolymerization and condensation reactions are carried out in conjunction with partial carbonization of the wood and the release of flammable gases. Due to aforementioned changes in the heat-treated wood, the wood becomes more resistant to biological pests and its hygroscopicity decreases [3, 19, 24].

Heat-treated wood can be executed by machine and also manually. However, when machining heat-treated wood, the blade must be well sharpened (cutting surfaces are smoother, thereby the cutting force is reduced). The problem with machining heat-treated wood can be the formation of fine dust that pollutes the work environment and can cause health problems for service personnel. Therefore, it is necessary to capture the resulting fraction during machining using special suction hoods in order to avoid inhalation of this dust. Another unpleasant fact about machining heat-treated wood is the specific odor generated by the release of aromatics [19]. The course of the blade in the milling is a cycloid because the cutting speed is much higher than the feed rate. The cutting path can be consider as a circle $[6,18]$.

In practice it is very important that the entire woodworking process proceeds with the smallest energy demand, while attaining the desired properties and quality of the machined surface [20]. Several factors influence the power demand of machinery [9], such as:

- selection of the appropriate cutting tool material,

- the geometry of the cutting tool,

- attributes of machined material,

- optimal cutting conditions (cutting speed, feed rate, tooth movement),

- cutting power. 
Cutting input and output power are the basic criteria for the evaluation of woodworking machines. The energy demand of the cutting process is most frequently observed by means of cutting power [2]. Cutting power $P_{c}$ is a power that is required to allow tool blades to cut off chips. It is the result of the scalar component of the force vector $F_{c}$ and the cutting speed vector $v_{c}$ :

$$
P_{c}=F_{c} \cdot v_{c}
$$

where:

$F_{c}$ is the force vector $[\mathrm{N}]$,

$v_{c}$ is the cutting speed vector [m. $\left.\mathrm{min}^{-1}\right]$.

With the known milling technology parameters, the cutting power can be determined as [16]

$$
P_{c}=\frac{a_{p} \cdot a_{e} \cdot v_{f} \cdot k_{c}}{60 \cdot 10^{3}}
$$

where:

$a_{p}$ is the cut depth [mm],

$a_{e}$ is the cut width [mm],

$v_{f}$ is feed rate $\left[\mathrm{mm} \cdot \mathrm{min}^{-1}\right.$ ],

$k_{c}$ is specific cutting force [N. $\left.\mathrm{mm}^{-2}\right]$.

Power is an important parameter necessary to determine energy costs and the load of electric power cables. If the machine is connected in a three-phase system, the power input of the electric motor is calculated from the following relation as the sum of inputs per phase [2]:

$$
P=U_{1} \cdot I_{1} \cdot \cos \varphi_{1}+U_{2} \cdot I_{2} \cdot \cos \varphi_{2}+U_{3} \cdot I_{3} \cdot \cos \varphi_{3}
$$

where:

$U_{1,2,3}$ are phase electric voltages [V],

$I_{1,2,3}$ are electric currents [A],

$\cos \varphi_{1,2,3}$ are power factors [-].

The cutting power $\left(P_{c}\right)$ can be calculated from measured input power values

$$
P_{c}=P_{t}-P_{o}
$$

where:

$P_{t}$ is total consumed power during working [W],

$P_{0}$ is consumed power during idling [W].

The goal of experiment is to determine the dependence of cutting power for milling picea abies as the most widespread wood species in Slovakia on the temperature of thermal modification of wood samples.

\section{MATERIAL AND METHODS}

The samples of wood picea abies were harvested from locality Vlčí jarok (Budča, Slovakia, 440 m.a.s.l.) and were cut into tables of $700 \times 100 \times 20 \mathrm{~mm}$. Four of them were thermally modified at the temperatures of $160,180,200$ and $220^{\circ} \mathrm{C}$ and one sample remained in the natural state. The samples were heat treated at the Arboretum of FLD (CZU in Prague) in Kostelec nad Černými lesy (Czech Republic) using ThermoWood technology in the LAC S 400/03 chamber KATRES s.r.o. (Figure 2). The samples were stored at the temperature of $10^{\circ} \mathrm{C}$. After removal from the chamber, they had the temperature of $60^{\circ} \mathrm{C}$. The thermal modification process was controlled by the program. The course of temperature changes (heating, treatment, cooling) over time is shown in the Fig. 3.

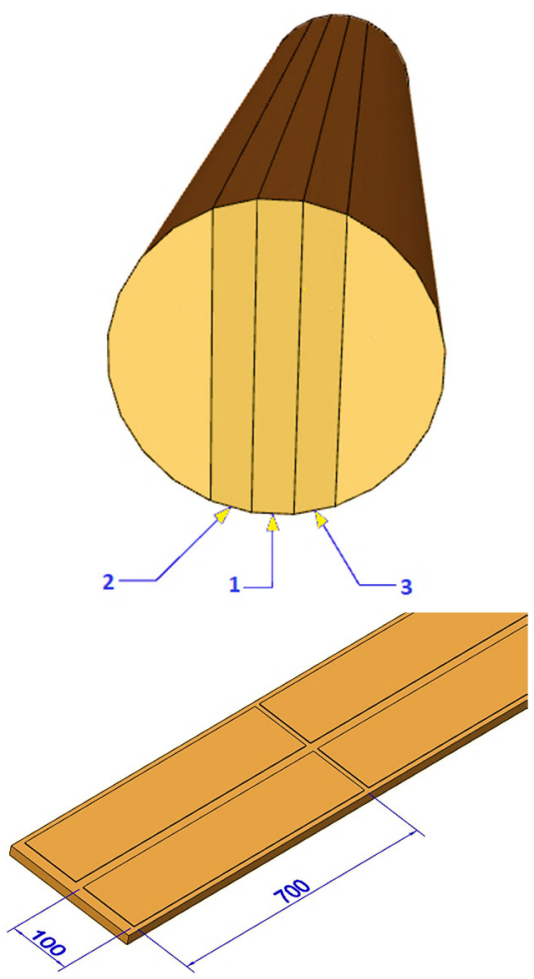

Fig. 1 Samples preparation

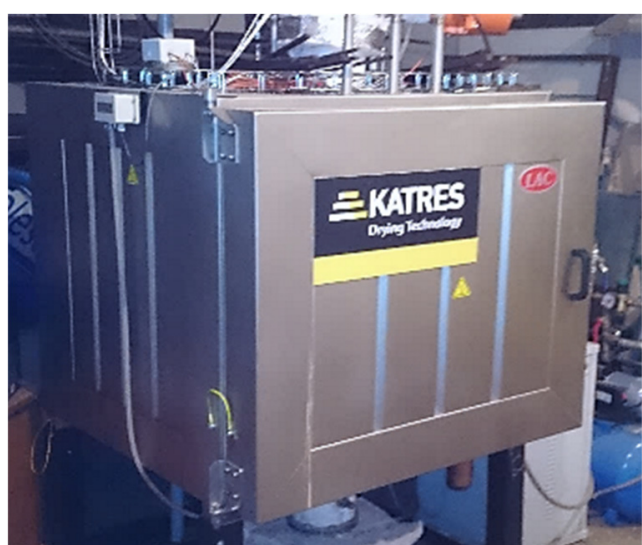

Fig. 2 LAC S S400/03 Chamber

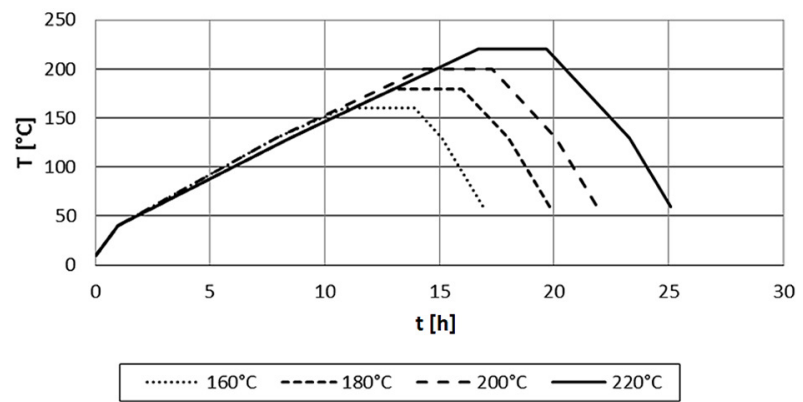

Fig. 3 Courses of heat treatment of spruce

Face milling was carried out by the FVS bottom milling machine (input power $4 \mathrm{~kW}$, supply voltage $360 / 220 \mathrm{~V}$, transient resistance $0.03 \Omega$, frequency $50 \mathrm{~Hz}$, manufacturing year 1976) with feeding mechanism Frommia ZDM 252/137 (feed rate 2.5/10/15/30 m. $\mathrm{min}^{-1}$, motor speed $2800 \mathrm{rpm}$, input power $0.55 \mathrm{~kW}$, supply voltage $380 \mathrm{~V}$ ) manufactured by Maschinenfabrik Ferdinand Fromm. 


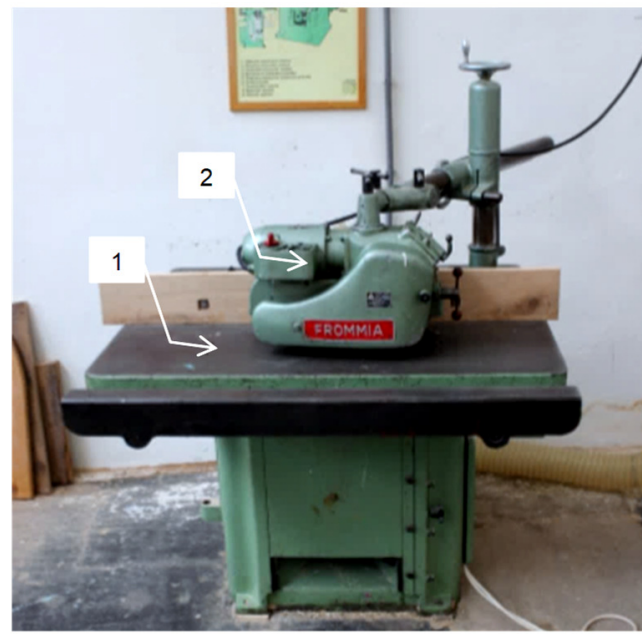

Fig. 4 Spindle miller (1) with feeding mechanism (2)

The speed of three phase asynchronous motor was controlled by means of frequency converter UNIFREM 400$007 \mathrm{M}$ (Fig. 5) which technical parameters are in the Table 1. The sinus filter has ensured that the impulse voltages from the converter have been softened to approximate ideal sinusoidal phases with a $120^{\circ}$ phase shift. The frequency converter measured the active motor power without considering the losses and motor power evaluated from the motor current, voltage and efficiency. All measured quantities can be viewed and stored on the external computer in VDS software (Vonsch Drive Studio) using the USB serial interface.

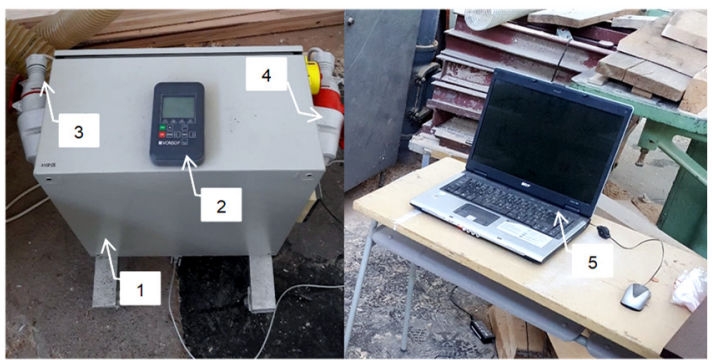

Fig. 5 Measuring device for power measurement 1) housing with frequency converter and sinus filter, 2) control panel UNIPANEL, 3) $3 f$ input, 4) 3f output, 5) laptop

Table 1

Technical parameters of frequency converter VONSCH UNIFREM 400 007M

\begin{tabular}{|c|c|c|}
\hline & Parameter & Value \\
\hline \multirow{3}{*}{$\begin{array}{l}\text { Quadratic } \\
\text { load }\end{array}$} & Motor power $\mathrm{P}_{\text {nom }}[\mathrm{kW}]$ & 7.5 \\
\hline & Nominal output current $I_{\mathrm{NQ}}[\mathrm{A}]$ & 18.1 \\
\hline & Motor power $P_{\text {nom }}[\mathrm{kW}]$ & 5.5 \\
\hline \multirow{3}{*}{$\begin{array}{l}\text { Constant } \\
\text { load }^{4)}\end{array}$} & Nominal output current $I_{\mathrm{NK}}[\mathrm{A}]$ & 13.2 \\
\hline & Max. output current $I_{N K 60}[A]$ & 19.8 \\
\hline & Max. output current $I_{\mathrm{NK} 2}[\mathrm{~A}]$ & 26.4 \\
\hline \multicolumn{2}{|c|}{ Nominal input current $I_{\mathrm{nIN}}[\mathrm{A}]$} & 18.4 \\
\hline
\end{tabular}

Figure 6 shows the connection of frequency converter VONSCH UNIFREM 400 007M.

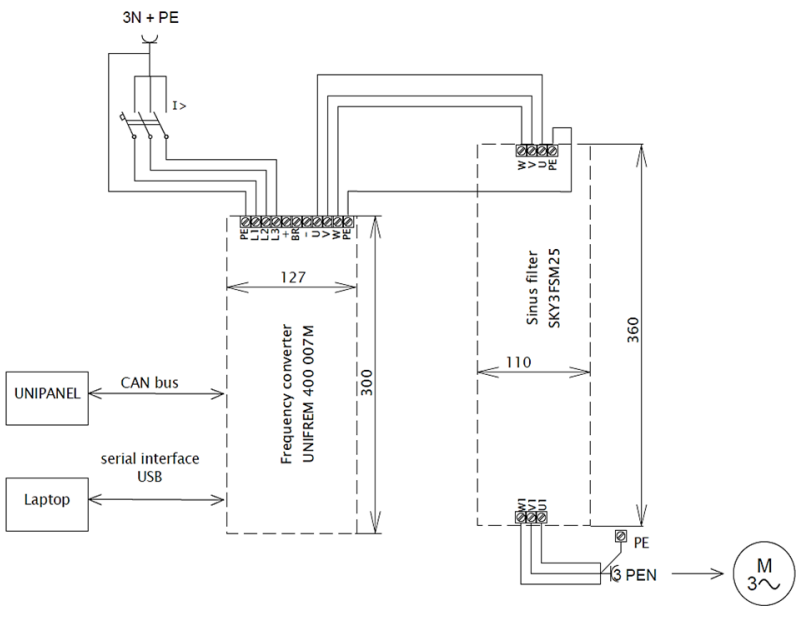

Fig. 6 Wiring of measuring equipment

Two blades were mounted in a cutting tool head, all with the $15^{\circ}$ rake angle. One of them was in the cut and took chips from the material, the other was used for balancing. The cut depth was adjusted to $1 \mathrm{~mm}$. 3 different blades were used:

1) from tool steel 19573 (STN 41 9573) with induction hardening provided by the Belarusian State Technical University and the Belarusian Academy of Sciences at the Physical-Technological Institute in Physical and Plasma Process Laboratories.

2) from steel HSS $18 \% \mathrm{~W}$ coated with AlTiCrN to the depth of $4 \mu \mathrm{m}$,

3) from tool steel Maximum Special 55: 1985/5 with the hardness of 64 HRC (Rockwell C Hardness) (WOOD-B, Nové Zámky, Slovakia)

Figure 7 shows the STANON FH 45 milling head with technical parameters in the Table 2 and cutting conditions in the Table 3.

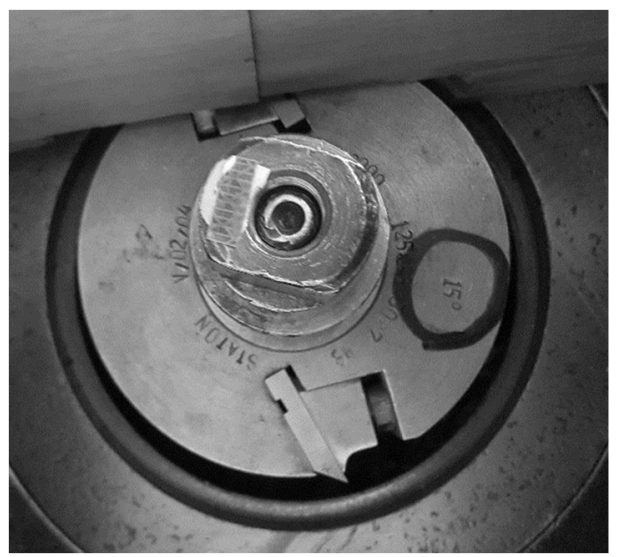

Fig. 7 Milling head with primary clearance angle of $15^{\circ}$

Table 2

Technical parameters of milling cutter with primary clearance angle of $15^{\circ}$

\begin{tabular}{lc}
\hline \multicolumn{1}{c}{ Parameter } & Value \\
\hline Miller head diameter [mm] & 125 \\
Miller head diameter with cutters [mm] & 130 \\
Miller head width [mm] & 45 \\
Diameter of clamping hole [mm] & 30 \\
Maximal revolutions [ $\left.\mathrm{min}^{-1}\right]$ & 8000 \\
Cutter number & 3 \\
\hline
\end{tabular}


Table 3

Cutting conditions

\begin{tabular}{|c|c|c|}
\hline \multicolumn{2}{|c|}{ Parameter } & Value \\
\hline \multirow{3}{*}{$\begin{array}{l}\text { Angle geometry of } \\
\text { the tool }\left[{ }^{\circ}\right]\end{array}$} & Rake angle $\gamma$ & 15 \\
\hline & $\begin{array}{l}\text { Primary clearance } \\
\text { angle } B\end{array}$ & 45 \\
\hline & Cut angle $\delta$ & 75 \\
\hline \multirow{5}{*}{\multicolumn{2}{|c|}{ Temperature of heat treatment $\left[{ }^{\circ} \mathrm{C}\right]$}} & Native \\
\hline & & 160 \\
\hline & & 180 \\
\hline & & 200 \\
\hline & & 220 \\
\hline \multirow{3}{*}{\multicolumn{2}{|c|}{ Cutting speed $v_{c}\left[\mathrm{~m} \cdot \mathrm{s}^{-1}\right]$}} & 20 \\
\hline & & 40 \\
\hline & & 60 \\
\hline \multirow{3}{*}{\multicolumn{2}{|c|}{ Feed rate $v_{f}\left[\mathrm{~m} \cdot \mathrm{min}^{-1}\right]$}} & 6 \\
\hline & & 10 \\
\hline & & 15 \\
\hline \multicolumn{2}{|l|}{ Cutting depth $a[\mathrm{~mm}]$} & 1 \\
\hline
\end{tabular}

Experimental measurement was carried out at the development workshops of the Technical University in Zvolen. 5 samples of spruce (Figure 8) were used for the measurements, one natural and four heat treated at temperatures of $160,180,200$ and $220^{\circ} \mathrm{C}$. The humidity of the samples was from 3 to $6 \%$. Samples were milled after stabilization of measured input power. Every sample was milled for two times for obtaining more relevant amount of data. The program recorded power and input power over time at a rate of about 15 data per second.

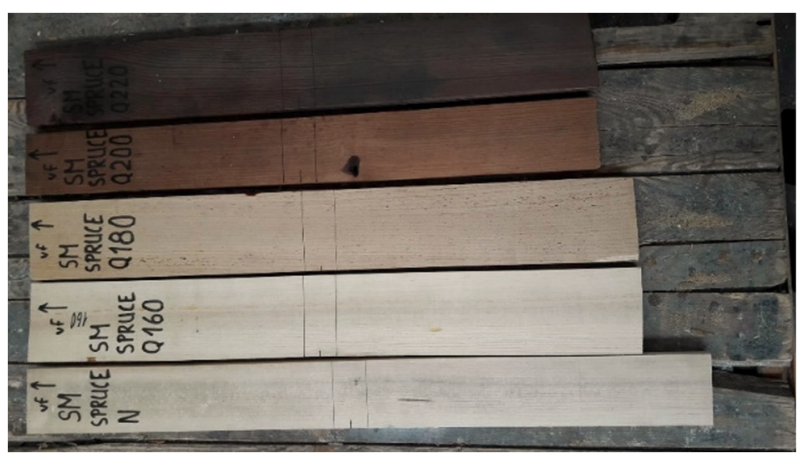

Fig. 8 Samples of spruce before milling

Determination of spruce wood density was carried out according to the standard STN 490108 . Twenty $20 \times 20 \times 30$ $\mathrm{mm}$ test samples obtained from experimental wood samples were measured on a digital caliper with the accuracy of $0.01 \mathrm{~mm}$ and weighted on laboratory scales with the accuracy of 0.01 grams. Density was calculated by relationship

$$
\rho=\frac{m}{V}
$$

where:

$\rho$ is the density of material $\left[\mathrm{kg} \cdot \mathrm{m}^{-3}\right]$,

$m$ is the mass of material $[\mathrm{kg}]$,

$V$ is the volume of material $\left[\mathrm{m}^{-3}\right]$.

Data was processed by MS Excel. Here, the measured data was reduced and removed when the milling cutter came in and out the cut. The idle cutter power was subtracted from the total input power during milling to obtain the cutting power that is needed to draw the cutting forces and overcome material resistances, eliminating asynchronous motor losses and transmission losses. Evaluation of statistical dependencies was carried out in STASTICA 12 software.

\section{RESULTS}

The effect of temperature of heat treatment of spruce wood on cutting power when planar milling is shown in the Fig. 9 wood and the lowest for the heat-treated wood at $220^{\circ} \mathrm{C}$. This corresponds to a decrease in density when increasing the temperature of the thermal modification, what causes reduction of the mechanical properties of wood. The wood structure is degraded and it becomes more brittle.

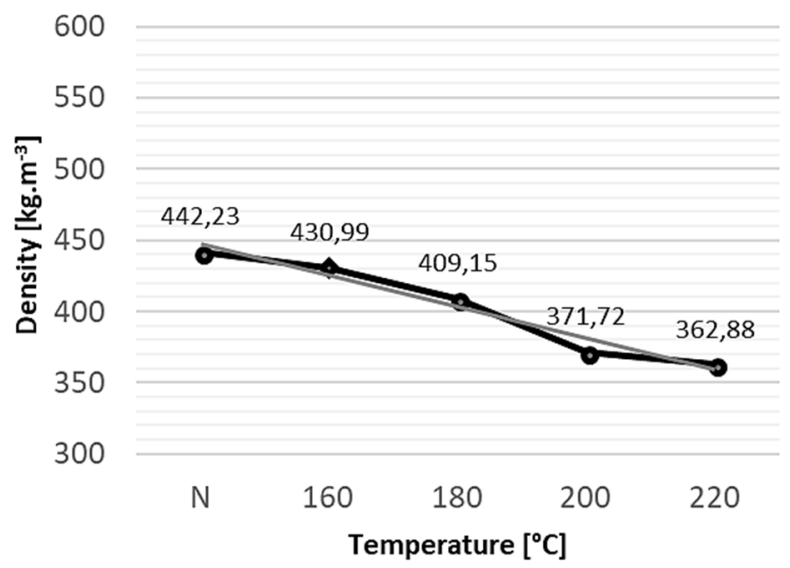

Fig. 9 Dependence of wood density on temperature of heat treatment

The calculated cutting power values of all combinations of the milling technology parameters were processed and statistically evaluated. The analysis of the variance of the measured data is shown in the graph in Fig. 10.

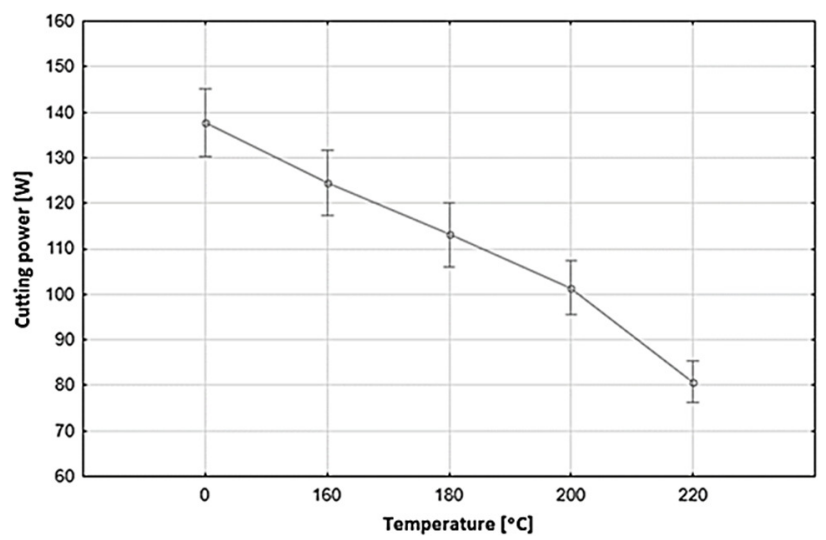

Fig. 10 Influence of heat treatment on cutting power-ANOVA

The highest mean value of the cutting power (137.6 W) was measured on a sample of native wood. This value was decreased (by $7.7 \%$ ) at the temperature of $160^{\circ} \mathrm{C}$. An almost uniform decrease in cutting power is visible at all modification temperatures. The biggest difference is between samples treated at temperatures of 200 and $220^{\circ} \mathrm{C}$, where the decrease is by $15 \%$ to the value of $80.8 \mathrm{~W}$. 
Native wood does not have a thermally degraded structure and therefore, the power required for milling is the largest. Thermal treatment reduces the mechanical properties of wood, disturbs hemicellulose, decreases the density, and makes wood less firm. The impact of the change in the technical properties of heat-treated wood is visible among the all wood samples. The increase in temperature became most evident in the deterioration of these properties and in the decrease in the power required for milling. Authors in [8] also point to the trend of decreasing total power when milling heat-treated oak wood at the same cutting conditions. The investigation of energy demand of native and thermally modified oak wood at a temperature of $165^{\circ} \mathrm{C}$ at a feed rate of $3 \mathrm{~m} / \mathrm{min}$, a cut depth of $2 \mathrm{~mm}$, a rotary mill speed of $3000 \mathrm{rpm}$ with a milling head with one knife in cut was described in [23]. Similarly, a reduction in the required power was shown, from $1099 \mathrm{~W}$ to $1033 \mathrm{~W}$. Authors in [11] showed a decrease in cutting power during milling beech native and thermally modified wood.

The level of statistical significance and the statistical difference in the effect of individual temperature treatments on the power consumption was evaluated using the posthoc Duncan's test (Table 4). The thermal modification significantly changes the value of the cutting power, and no set of measured data is similar to another. The heat modification temperature therefore has a statistically significant effect on the cutting power values of the plane milling process.

Average weighted values of cutting power with standard deviation are in the Table 5. The highest average power value was recorded for native wood, (137.674 W). On the other hand, the lowest average power value was recorded for the material heat-treated at $220^{\circ} \mathrm{C}(80.795 \mathrm{~W})$.

Table 4

Duncan test of influence of heat treatment on cutting power

\begin{tabular}{cccccc}
\hline Temp. $\left[{ }^{\circ} \mathrm{C}\right]$ & $\mathbf{0}$ & 160 & 180 & 200 & $\mathbf{2 2 0}$ \\
\hline $\mathbf{0}$ & & 0.000009 & 0.000011 & 0.000003 & 0.000004 \\
160 & 0.000009 & & 0.000022 & 0.000011 & 0.000003 \\
180 & 0.000011 & 0.000022 & & 0.000016 & 0.000011 \\
200 & 0.000003 & 0.000011 & 0.000016 & & 0.000009 \\
220 & 0.000004 & 0.000003 & 0.000011 & 0.000009 & \\
\hline
\end{tabular}

Table 5 Average weighted values of cutting power Cutting power $[\mathrm{W}]$

\begin{tabular}{ccccc} 
Temperature $\left[{ }^{\circ} \mathrm{C}\right]$ & Average & St. dev. & $\mathbf{- 9 5 . 0 0 \%}$ & $\mathbf{+ 9 5 . 0 0 \%}$ \\
\hline $\mathbf{0}$ & 137.674 & 3.796 & 130.192 & 145.155 \\
$\mathbf{1 6 0}$ & 124.449 & 3.594 & 117,365 & 131.532 \\
$\mathbf{1 8 0}$ & 113.075 & 3.554 & 106.069 & 120.081 \\
$\mathbf{2 0 0}$ & 101.409 & 3.006 & 95.485 & 107.333 \\
$\mathbf{2 2 0}$ & 80.795 & 2.282 & 76.297 & 85.293 \\
\hline
\end{tabular}

\section{DISCUSSION}

The energy consumption when face milling of picea abies decreases with increasing of temperature of heat treatment. Changes occurring at higher temperatures cause degradation of the wood, its mechanical properties deteriorate and wood becomes more brittle. The smallest average value of the cutting power $(80.795 \mathrm{~W})$ was measured at $220^{\circ} \mathrm{C}$, the highest $(137.674 \mathrm{~W})$ for native wood.

Authors in [10] examined the energy consumption when face milling of beechwood, in [13] birch and in [15] oak wood. They also claim that the temperature of the thermal modification has a statistically significant effect on the energy consumption of the face milling and with the increasing temperature the total and cutting power has a decreasing trend, although in [15] authors measured a slight increase of total power at the last sample.

Furthermore, variations could be due to undesired irregular thermal treatment of samples of spruce wood. For example, the centre of the heat-treated sample at $220^{\circ} \mathrm{C}$ was lighter than its region. Further research of the heat transfer of selected thermally modified wood by a holography interferometer could prove the values of the heat transfer coefficients [5, 17]. Also the blunting of cutting tool influences the energy consumption when milling [12] what is possible to evaluate by optical analysis of fractional particles arising during machining [7].

Further research will be focused on the impact of cutting speed, feed rate, and blades sets on the energy consumption when face milling of spruce as well as other woods species. The research of the evaluation the machining process by optical analysis of fractional particles is also expected.

\section{CONCLUSION}

Temperature of heat treatment of spruce wood has proved to be a statistically significant factor when the flat milling of the prepared samples. The thermal modification changes the mechanical properties of the wood, reduces its density, the wood becomes more brittle and the forces necessary to separate the material decrease. As other parameters of the technological machining process were changed, further analysis suggests an analysis of the impact of these factors as well.

The energy consumption of the machining process is one of the assessment criteria of economic intensity in relation to the environment. By reducing electricity consumption by adhering to the prescribed and desired mechanical and aesthetical properties of the resulting product, the machining process is optimized and the direct costs are reduced. Also, the load on the electric net is reduced, which could be interesting to production plants with larger production volumes.

\section{ACKNOWLEDGEMENTS}

Contribution has been prepared within the solving of scientific grant project VEGA 1/0315/17 " Research of relevant properties of thermally modified wood at a contact effects in the machining process with the prediction of obtaining an optimal surface." 


\section{REFERENCES}

[1] Š. Barcík and T. Homola. "Effect of selected parameters on the quality of machined surface at planar milling of juvenile pine wood", in Proceedings of the Chip and Chipless Woodworking, 2004, pp. 31-36.

[2] Š. Barcík and T. Rehák. Effect of selected technical, technological and material factors on the energetic efficiency at planar milling. Prague: Czech University of Life Sciences, 2009.

[3] C. Bengtsoon, J. Jermer, A. Clang and B. Ek-Olausson. "Investigation of some Technical Properties of Heattreated Wood". Brisbane: International Research Group on Wood Protection, 2003.

[4] M.J. Boonstra, J. van Acker and A. Pizzi. "Anatomical and molecular reasons for property changes of wood after full-scale industrial heat-treatment", in Proceedings of the Third European Conference on Wood Modification, 2007, pp. 343-358.

[5] J. Černecký, J. Jandačka, M. Malcho, J. Koniar and Z. Brodnianská. "Effect of the positions of directional tubing towards shaped heating surfaces on the value of local heat transfer coefficients". JP Journal of Heat and Mass Transfer, vol. 12, no. 1, pp. 15-30, 2015.

[6] J. Lisičan. Theory and technique of wood working. Zvolen: MAT-CENTRUM, 2007.

[7] P. Koleda and M. Hrčková. "Global and Local Thresholding Techniques for Sawdust Analysis." Acta Facultatis Technicae, vol. 23, no. 1, pp. 33-42, 2018.

[8] P. Koleda, Š. Barcík, M. Vančo and A. Nociarová. "Thermal Treatment and Its Effect on Energetic Efficiency of Thermal Treated Oak Wood Face Milling". Acta Facultatis Technicae, vol. 22, no. 2, pp. 63-74, 2017.

[9] J. Krilek, J. Kováč and M. Kučera. "Wood cross cutting process analysis for circular saws", BioResources, vol. 9, no. 1, pp. 1417-1429, 2014.

[10] J. Kubš. "Influence of Selected Factors on the Energy Performance of Flat Milling of Thermally Modified Wood". M.A. thesis, Czech University of Life Sciences, Prague, Czech Republic, 2013.

[11] J. Kubš, M. Gaff and Š. Barcík. "Factors affecting the consumption of energy during the milling of thermally modified and unmodified beech wood". BioResources, vol. 11, no. 1, pp. 736-747, 2016

[12] Mazáň, M. Vančo and Š. Barcík. "Influence of technological parameters on tool durability during machining of juvenile wood". BioResources, vol. 12, no. 2, pp. 2367-2378, 2017.

[13] E. Miftieva. "Influence of Technical - technological and Material Factors of Planar Milling of Thermally Modified Birch Wood on Energy Performance during Shaping". M.A. thesis, Czech University of Life Sciences, Prague, Czech Republic, 2014.

[14] P. Niemz, T. Hoffmann and T. Retfalvi. "Investigation of chemical changes in the structure of thermally modified wood". Maderas Ciencia y Tecnologia, vol. 12, no. 2, pp. 69-78, 2010.
[15] Nociarová. "Effect of technical and technological independent parameters on energetic consumption when planar milling of heat-treated oak wood". M.A. thesis, Technical University in Zvolen, Slovakia, 2017.

[16] E.L. Olteanu, C.F. Bîşu and I. Tănese. "Determination of power consumption in Milling". U.P.B. Scientific Bulletin, vol. 75, no. 4, pp. 211-220, 2013.

[17] E. Pivarčiová. "Analysis of concentration fields holograms", in Informatics and Automation in Process Control, Zvolen, 2012.

[18] S. Prokeš. Working of Wood and New Wood Materials. Prague: SNZL, 1982.

[19] L. Reinprecht and Z. Vidholdová. Thermowood Preparation, Characteristics and Applications. Zvolen: Technical University in Zvolen, 2008.

[20] S. Thiede, G. Bogdanski and C. Herrmann. "A systematic method for increasing the energy and resource efficiency in manufacturing companies", in 1st CIRP Global Web Conference: Interdisciplinary Research in Production Engineering, no. 2, 2012, pp. 18-33.

[21] M. Vančo, Z. Jamberová, Š. Barcík, M. Gaff, H. Čekovská and L. Kaplan. "The effect of selected technical, technological, and material factors on the size of juvenile poplar wood chips generated during face milling". BioResources, vol. 12, no. 3, pp. 48814896, 2017.

[22] M. Vančo, A. Mazáň, Š. Barcík, L. Rajko, P. Koleda, Z. Vyhnáliková and R.R. Safin. "Impact of selected technological, technical and material factors on the quality of machined surface at face milling of thermally modified pine wood". BioResources, vol. 12, no. 3, pp. 5140-5154, 2017.

[23] J. Wilkowski, M. Grześkiewicz, P. Czarniak, I. Siwek, L. Javorek and D. Pauliny. "Influence of thermal modification of oak wood on cutting forces during milling". Annals of Warsaw University of Life Sciences - SGGW Forestry and Wood Technology, vol. 76, pp. 203-207, 2011.

[24] B.J. Zobel and J.R. Sprague. Juvenile Wood in Forest Trees. Berlin: Springer-Verlag, 1998.

\author{
Ing. Peter Koleda, PhD. \\ Ing. Michal Korčok \\ Prof. Ing. Štefan Barcík, CSc. \\ Ing. Štefan Il'aš \\ Technical University in Zvolen \\ Faculty of Environmental and Manufacturing Technology \\ T. G. Masaryka 24, 960 53, Zvolen, Slovak Republic \\ e-mail: peter.koleda@tuzvo.sk
}

